\title{
Verdenssyn og menneskesyn i Grundtvigs salmedigtning*
}

\author{
Af Peter Balslev-Clausen
}

Det er Grundtvig-forskningens opgave at klarlægge og formidle Grundtvigs tanke- og forestillingsverden. Det følgende er et fors $\emptyset \mathrm{g}$ på at sammenfatte resultatet af et omfattende studium af Grundtvigs salmedigtning. Der er ikke tale om en gennemgang af hans salmedigtning som sådan, men om at bestemme det menneskelige og kristelige helhedssyn, der danner baggrund for den, som et bidrag til en $\emptyset$ get forståelse af Grundtvigs salmedigtnings personlige og åndshistorisk-teologiske sammenhæng.

Fremstillingen vil forme sig som en gennemgang af centrale grundtvigske begreber. Selvom der kun i forholdsvis få tilfælde vil blive henvist direkte til enkelte salmer, hviler fremstillingen på studier af hele Grundtvigs salmedigtning. En sammenligning med Grundtvigs $\emptyset$ vrige produktion ville sprænge rammerne for nærværende fremstilling, men en sådan ville kun understrege sammenhængen $\mathrm{i}$ hans forestillingsverden.

På trods af at Grundtvig i vid udstrækning tænkte i uforligelige modsætninger, liv og død, sandhed og løgn, lys og mørke, er 'sammenhæng' et af de vigtigste begreber, når man vil forsøge at trænge ind $\mathrm{i}$ hans forestillingsverden. Ikke romantikkens dialektiske organismetænkning - Grundtvigs uforligelige modsætninger var uforligelige - men den bibelske, skabelses- og frelseshistoriske sammenhæng mellem Gud og mennesker og mellem mennesker indbyrdes. For denne sammenhængs skyld fastholdt han det gamle verdensbillede og bekrigede det nye med næb og kløer som Antikrists værk, - ikke af misforstået konservatisme, fordi han var bange for det nye som sådant og ikke vidste bedre - men fordi det nye verdensbillede, sådan som han opfattede det, umuliggjorde enhver forestilling om sammenhæng mellem Gud og mennesker,

* Licentiatforelæsning på Københavns Universitet, Det teologiske fakultet, 24. februar 1989, over emnet: "Udviklingslinier i Grundtvigs salmedigtning med særligt henblik på forholdet mellem det menneskelige og det kristeligen". 
himmel og jord, skabelse og fuldendelse, fortid, nutid og fremtid, og uden denne sammenhæng ville mennesket miste både sin identitet med sig selv og sit fællesskab med andre.

Det er næppe muligt for nogen i dag at gøre Grundtvigs forudsætninger til sine. Det er ikke mange, der i sit daglige liv kan tage det verdensbillede alvorligt, som Grundtvig siden 1810 kæmpede for at fastholde som kristendommens nødvendige forudsætning. Det hermeneutiske spørgsmål om muligheden af at bruge fortidige tekster i en aktuel sammenhæng melder sig derfor i fuld styrke i forbindelse med Grundtvigs produktion. Det gælder ikke mindst hans salmer, der ikke alene udtrykker hans tankegang i den endelige, afklarede form, men den dag i dag bruges $i$ gudstjenesten som menighedens eksistentielle livsudtryk.

Spørgsmålet er, om Grundtvigs konklusioner kan bruges, når hans præmisser ikke længere er anvendelige . Kan den virkelighed, Grundtvig vil fastholde og formidle gennem sine salmer, stadig opleves som en levende, nærværende virkelighed? Kan den det - ja, så kan salmerne stadig bruges, på trods af deres fremmedartethed.

På grund af Grundtvigs levende bevidsthed om verdensbilledets, forståelses-paradigmets betydning fastholder han, netop ved sin fremmedartethed, sin læser og sin bruger i salmesangen på den kendsgerning, at den sidste, eksistentielle tilegnelse altid er hans og hendes ansvar - udfra de forudsætninger, der er hans og hendes egne, individuelle og tidsbestemte. Men dette sidste, nødvendige arbejde kan man kun gøre, når man véd, hvad det var Grundtvig mente og udtrykte. At gøre rede for, hvad dét var, er Grundtvig-forskningens opgave, også i den følgende korte fremstilling.

\section{Ordet}

Ordet er såvel menneskeligt som kristeligt Grundtvigs grundlæggende begreb. Ordet, det talte ord, er bærer af den enkeltes livsfællesskab med Gud og mennesker, og det er det grundlæggende udtryk for menneskeligt og kristeligt fællesskab overhovedet. Den, der taler, giver gennem sin tale udtryk for, hvem han er, og tager den, han taler til, med i sit liv, sådan som han er. På samme 
måde åbner den, der hører, sig for den, der taler, og tager også ham med $\mathrm{i}$ sit liv, ligeledes uden forbehold. Talen formidler sammenhæng, livsfællesskab, mellem den, der taler og den, der hører (og omvendt), og er derved et udtryk for den åndelige virkelighed, som de begge er en del af. Det er det fælles sprog som formidler af det indbyrdes livsfællesskab, der konstituerer et folk - det er i denne sammenhæng Grundtvigs tale om folkeånd skal forstås - på samme måde som det er den fælles bekendelse, forkyndelse og lovsang, der er det kirkelige fællesskabs udtryk.

Ordet, talen, er for Grundtvig det egentlige udtryk for menneskets gudbilledlighed. Ligesom moderen åndeligt talt genføder sit barn, når hun lærer det at tale og derved deler sin åndelige sammenhæng, sit åndelige liv med det, genfødte Gud åndeligt talt Adam i sit billede som menneske til forskel fra dyrene, da han indblæste sin livsånde $\mathrm{i}$ ham og talte til ham. Gud lærer vi at kende gennem hans skaberord, gennem hvilket han delte sit liv med den verden, han skabte ved at udtale det. Det er Guds ord, der lød gennem profeterne, og det er hans ord, der i Jesus Kristus i forløsningens gentagne skaberakt, 'blev kød og tog bolig iblandt os'. Endelig er det Guds ord, der gennem pinseunderet blev den åndelige virkelighed, der holder verden sammen. Fordi sproget er bærer af menneskets åndelige liv, er det gennem Helligåndens komme og sprogunderet Pinsedag blevet bærer af og udtryk for Guds liv med mennesker. Det menneskelige og det kristelige hører i den enkeltes, men også i kirkens - og folkets - liv i den grad sammen som hinandens gensidige forudsætning, at de ikke kan skilles ad. Al tale er i virkeligheden et udtryk for Guds skaberord og bærer af det grundlæggende livsfællesskab med Gud, selvom det efter syndefaldet ikke længere står i menneskers magt at tale det frit med Gud eller med hinanden. Guds ord har dog stadig sin usvækkede skaberkraft i Jesus Kristus og i sakramenterne dåb og nadver, der skaber og opretholder livsfællesskabet med ham:

Ingen kan til Himmels fare,

Uden hvo derfra nedfoer,

Og selv Himlens Engle-Skare

Vinge laaner af Guds Ord,

Men i Badet og ved Bordet

Vi blev Eet med Guddoms-Ordet (SV 1,114.15) 
Stærkere kan det næppe udtrykkes, at ordet, Guds ord, er bærer af livfællesskabet mellem Gud og mennesker. Derfor er Guds ord det faste holdepunkt, det er ikke verden, som Gud har skabt, men Guds ord, der har skabt verden, der står fast.

Som bærer af den åndelige virkelighed er ordet ikke bundet af hverken tid eller sted, men formidler tilværelsens historiskpoetiske sammenhæng, som bibelsk profeterne sikrer ind $i$ fremtiden og menneskeligt digterne - skjaldene- sikrer tilbage til fortiden.

Forudsætningerne for Grundtvigs opfattelse af ordets betydning og sammenhæng er skabelsesberetningen i begyndelsen af 1 . Mosebog og Johannes-evangeliet, ikke mindst evangeliets indledning, hvor ordet er udtryk for Guds skaberkraft og forløsningsvilje. Det er tydeligt, at Grundtvigs forståelse af ordets og talens betydning i forlængelse af det "Guddomsord, der skaber, hvad det nævner" ikke kan forenes med naturvidenskabelig forståelse af talen som frembringelse og opfattelse af lydbølger med en på forhånd $\mathrm{i}$ den afsendende og modtagende hjerne fastlagt betydning. Den moderne naturvidenskabs fysisk-biologiske opfattelse af ord og tale gør Grundtvigs tale om ord som and til poetiske metaforer og digteriske allegorier, hvilket er noget helt andet end den umiddelbare menneskelige og guddommelige virkelighed, Grundtvig forestillede sig.

\section{Verdensbilledet}

Jo mere man beskæftiger sig med Grundtvigs tankeverden, jo mere får man indtryk af dens forankring i et førvidenskabeligt verdenssyn. Tydeligst viser dette sig i den kategoriske afvisning af det kopernikanske verdensbillede. Grundtvig holdt hele sit liv fast ved det, som han selv kaldte det kaldæiske verdensbillede, og han var på intet tidspunkt $\mathrm{i}$ tvivl om, at det kopernikanske verdensbillede måtte afvises som stridende mod både Bibel og Trosbekendelse, rent bortset fra, at enhver med sine egne øjne kunne se, at det var solen, der gik rundt omkring jorden og ikke omvendt. Jorden var efter Grundtvigs opfattelse det ubestridte centrum i det gudskabte univers, her levede mennesket, som Gud havde skabt i sit billede og indblæst med sin livsånde, og her blev hans 
enbårne Søn født til verden. Herfra var Kristus faret til Himmels op gennem verdensrummet, og herfra hævede salmesangen sig sammen med englenes sang til den himmel, hvorfra englene havde bragt den evige lovsang ved verdens skabelse og igen ved Jesu fødsel. Når Grundtvig talte om, at himlen åbnede sig ('da åbner sig Himlens borgeled'), og når han talte om at gå til kirke på 'stjernetæpper lyseblå', mente han det helt bogstaveligt og ikke i overført, digterisk betydning, sådan som de fleste, der synger hans salmer, utvivlsomt gør. Englesangen var for Grundtvig, hvad sfærernes harmoni var for grækerne, hvilket igen betød, at han opfattede salmesangen som menneskers tilegnelse af og udtryk for denne den gudskabte verdens universelle samklang med sin skaber.

Det var Grundtvigs faste overbevisning, at universets og dermed tilværelsens sammenhæng ville gå tabt, hvis man måtte opgive det kaldæisk-ptolemæiske verdensbillede. Evigheden ville blive tomhed og intethed, og mennesket som en del af skabningen ville være 'som græsset, der står i dag og i morgen kastes i ilden,' d.v.s. en ligegyldig tilfældighed. Som Grundtvigs krisedigte fra 1840'rne til og med 'Urolige Hjerte' fra 1851 viser det, har han været anfægtet af det moderne verdensbillede, men han har stædigt forkastet det for at kunne overleve med sin såvel menneskelige som kristelige identitet $\mathrm{i}$ behold.

\section{Tidsregningen}

Grundtvig har i det store og hele stået alene med sin, som han kaldte den, mosaisk-kristelige anskuelse. Det viser sig med samme tydelighed, når det drejer sig om hans kronologiske, som når det drejer sig om hans astronomiske verdensbillede. Når Grundtvig gendigtede Psalme 90 og skrev "For dig, o Herre, som dage kun / Årtusinder er at regne", var det ikke alene forskellen på den guddommelige og den menneskelige tidsfornemmelse, han havde i tankerne, men det forhold, at verdensløbet fra skabelsen til fuldendelsen svarede til skabelsesugen fra kap. 1 i 1 . Mosebog, sådan at en skabelsesdag svarede til tusinde verdensår. Denne jødisk-oldkirkelige kronologi hørte med som en fast, ufravigelig bestanddel af Grundtvigs mosaisk-kristelige anskuelse, idet tiden efter tidsløbets midte, Kristi fødsel, udfra menighedsbrevene i 
Johannes Åbenbarings kap. 2 og 3 var underopdelt i de 7 hovedmenigheders tidsaldre, den hebraiske, den græske, den latinske, den engelske, den tyske, den danske (eller nordiske ) og den endelige syvende menigheds tidsalder. Dette universalhistoriske skema udgør den faste struktur i såvel hans kirkelige som hans verdslige kronologi.

Når det var så vigtigt for Grundtvig at fastholde den jødiskkristne universalhistoriske kronologi, skyldes det ikke alene, at det var Bibelens kronologi, men også at det, menneskeligt set, var muligt udfra denne kronologi at få et på engang fast og levende forhold til såvel fortid som fremtid. Grundtvig sammenlignede tidsløbet med en strøm - af liv - fra skabelsen til fuldendelsen, hvor hvert afsnit af strømmen, samtidig med at det forblev sig selv, som forudsætning for netop at forblive sig selv til stadighed modtog og videregav en fortsat strøm af liv.

Grundtvig vidste, at det kopernikanske verdensbillede ville sprænge denne tidsstruktur; fortid, nutid og fremtid ville blive relative størrelser, som det ikke ville være muligt at forholde sig absolut til, som i den gamle struktur, skabelsen ville ikke længere være historiens begyndelse $\mathrm{i}$ Bibelens forstand, og fremtiden ville ikke mere kunne begrunde noget hverken menneskeligt eller kristeligt håb. Det er $\mathrm{i}$ denne sammenhæng også Grundtvigs brud med Ingemann skal ses, p.g.a. dennes kosmologiske evighedsforståelse og den deraf følgende opgivelse af troen på 'kødets opstandelse', der forudsætter både det ptolemæiske verdensbillede og den jødisk-kristne kronologi, rent bortset fra, at Trosbekendelsen som Guds ord til sin menighed efter Grundtvigs opfattelse nødvendigvis måtte have prioritet $\mathrm{i}$ forhold til enhver menneskelig teori.

\section{Den historiske sammenhaeng}

Det universal-historiske tidsskema giver ikke alene Grundtvig en fast tidsramme at operere med, han véd f.eks. udfra den universalhistoriske tidsregning, at verdensløbets afslutning vil finde sted år 2.239, det giver ham også en fornemmelse af historiens organiske sammenhæng og paralleliteten mellem historiens forskellige niveauer. 
Den grundlæggende universalhistoriske struktur er allerede nævnt. Indenfor denne struktur forestiller Grundtvig sig en vekselvirkning mellem den kollektive og den individuelle og mellem den kirkelige og den verdslige historie. Den kollektive historie afspejler sig i den individuelle historie og omvendt, og på samme måde er det med den kirkelige og den verdslige historie.

Grundtvig opfatter historiens organiske sammenhæng historiskpoetisk, idet han forstår det poetiske som dén produktive sammenhæng, der historisk forstået er det tids- og sted-transcenderende livsfællesskab ikke alene mellem Gud og mennesker, men også mellem mennesker indbyrdes. Denne dobbelte livssammenhæng er det profeternes - og skjaldenes - opgave at foregribe og fortolke såvel på det bibelsk-kirkelige og folkelige som på det individuelt-personlige plan.

Det er i denne sammenhæng Grundtvigs opfattelse af mindet skal forstås. Mindet er den produktive erindring, der menneskeligt og folkeligt binder fortid, nutid og fremtid sammen, og er således et historisk-poetisk hovedbegreb. Ud fra den nordiske mytologi forestiller Grundtvig sig skjalden som den, der ved at holde mindet $\mathrm{i}$ hævd sikrer fortidens og dens menneskers eksistentielle nærvær i nutid og fremtid. I denne sammenhæng, som den skjald, der i sig samler såvel den kirkelige som den folkelige hovedstrøm, opfatter Grundtvig sig som den store eskatologiske skikkelse i den danske kirke. Som sådan var det nødvendigt for ham at hævde det gamle verdensbillede, den mosaisk-kristelige anskuelse, der holdt historien fast i spændingsfeltet mellem skabelse og fuldendelse. Det var denne historisk-poetiske forståelse, der for Grundtvig gav den danske kirke dens profetiske sammenhæng udfra Esaias 49,1: "Herren taler: Øer hører", og som gjorde, at han stædigt holdt fast ved sin forudsigelse af den danske kirkes eskatologiske gennembrud, indtil han mente at have oplevet det juledag 1845, da den nye salmesang brød igennem i Vartov Kirke. Det er betegnende for Grundtvigs opfattelse af sin egen rolle, at han på det personlige plan satte sit møde med Marie Toft nogenlunde samtidig ind i denne sammenhæng ved siden af den folkelige genfødelse gennem Treårskrigen og Grundlovens givelse et par år efter 1845. Det er denne kombination af bibelsk, kirkeligt, personligt og nationalt-folkeligt, der er baggrunden for gendigtningen 1864 af Psalme 65, "Højhedens Gud, som kom herned", hvor krigen og ne- 
derlaget ses som Guds prøvelse af den danske kirke og det danske folk, - og af Grundtvig selv som den både kirkeligt og folkeligt set eskatologiske integrationsfigur. Grundtvigs både anfægtede og hårdnakkede afvisning af det moderne verdensbillede skyldtes, at han "vidste, / At han var den Sidste,/ Der fødtes til Syner og Sang". Som den profetiske skjald var det ham, der skulle sikre den dynamisk-eskatologiske sammenhæng mellem fortid og fremtid. En sådan forståelse, ikke mindst en sådan selvforståelse, forudsatte en fastholdelse, koste hvad den ville, ved det ptolemæiske verdensbillede og det jødisk-oldkristne historiesyn.

\section{Menneskeligt og kristeligt}

Det menneskelige og det kristelige var for Grundtvig hele livet igennem to sider af samme sag. Selvom Grundtvig flere gange i løbet af sit liv, ikke mindst $\mathrm{i}$ årene lige efter 1830 ændrede sit syn på det indbyrdes forhold mellem det menneskelige og det kristelige, forblev den grundlæggende opfattelse nogenlunde den samme, på samme måde som hans verdensbillede og hans bibelskkristne historiesyn var uændret lige til hans død.

Det ufravigelige udgangspunkt i Grundtvigs mosaisk-kristelige anskuelse var, at Gud har skabt verden, og at alt levende har del i skabningens livsfællesskab med ham. Dernæst stod syndefaldet og verdens afslutning ved dagenes ende for Grundtvig fast som kendsgerninger alle mennesker både kunne og måtte anerkende. Det var således ikke verdenssynet, der behøvede at skille kristne og ikke-kristne. De ikke-kristne, der kunne anerkende det grundlæggende livsfællesskab mellem Gud og mennesker, d.v.s. dem, som Grundtvig kaldte hedninger eller naturalister med ånd, kunne han fuldt ud samarbejde med på det rent menneskelige plan, dem kunne han holde skole med, som han sagde, hvad han ikke kunne med de naturalister, der ikke havde forståelse for tilværelsens åndelige sammenhæng, men udfra en moderne videnskabelighed havde en materialistisk verdensforståelse, hvor al sammenhæng var opløst i sine mindste bestanddele, der hver for sig betød alt, og derfor i virkeligheden intet betød. I modsætning til naturalisterne med ånd, for hvem mennesket stadig var skabt i Guds billede med levende ord på sin tunge, og for hvem det 
grundlæggende livsfællesskab med Gud også var menneskers livsfællesskab med hinanden indenfor skabelsens og historiens faste strukturer, der gentog sig selv ned i de mindste sammenhænge, var der for det materialistiske menneske kun dets egen sammenhæng og kun de strukturer, som det var i stand til selv at skabe sig i sin egen 'selv-klogskab'; og det var ikke nok til at bære et fællesskab mellem mennesker, men ville tvært imod opløse ethvert sådant fællesskab.

Grundtvigs ideologiske hovedmodstandere var i denne forbindelse oplysningstidens repræsentanter, hvadenten de optrådte i en folkelig-kulturel eller i en kirkelig-teologisk sammenhæng. Grundtvig veg ikke tilbage fra at kalde rationalisterne, der over en bred front fors $\emptyset$ gte at forene, hvad de forstod som kristendommens grundlæggende værdier, med det $\mathrm{i}$ videste forstand moderne verdensbillede, for Antikrist og kristeligt set afskrive dem som den fortabelsens æt, der havde sat sig selv udenfor livsfællesskabet med Gud.

Grundtvig skrev sine salmer i frontlinien mellem liv og død, sandhed og løgn, lys og mørke som udtryk for det guddommeligtmenneskelige livsfællesskabs vilkår. Salmerne er skrevet udfra den overbevisning, at de, som den kristne tilværelse iøvrigt, er en jordisk ramme om et himmelsk indhold, et levende udtryk for inkarnationens forening af det guddommelige og det menneskelige. Derved repræsenterer salmerne en forening af det menneskelige og det kristelige, hvor alt: ord, versemål, begreber, strukturer, også indholdsmæssige, indgår i en organisk enhed tilsyneladende uden synlige overgange. Herved åbner salmerne sig på én gang mod naturalisten med ånd og hans oplevelse af tilværelsen, samtidig med at de umærkeligt fører deres læsere og brugere ind i det kristne univers.

Naturalisten med ånd er efter Grundtvigs opfattelse som børnene i "Velkommen igen, Guds engle små", der ubevidst, drømmende aner den kristne sammenhæng, som de senere bevidst oplever som også deres egen virkelighed i gudstjenestens - og salmesangens - livsfællesskab med Gud. Det menneskelige har intet selvstændigt rum ved siden af det kristne, men er, samtidig med at det er en fuldt legitim oplevelse af skabelsens og skabningens virkelighed, en foreløbig erkendelse af den i kristendommen fuldt udfoldede virkelighed. 
Ud fra sin opfattelse af forholdet mellem det menneskelige og det kristelige afviser Grundtvig såvel den pietistiske afsporing af det kristelige som den rationalistiske afsporing af det menneskelige med den begrundelse, at pietisterne glemmer sammenhængen med skabningen og rationalisterne glemmer sammenhængen med skaberen. Begge dele, både skaberen og skabningen, hører med til den tilværelsessammenhæng, det livsfællesskab, der er konstituerende for den menneskeligtkristelige eksistens. Hvad der styrker denne sammenhæng er af det gode, er i pagt med sandheden - det er derfor Grundtvig især efter 1832 har et udtalt positivt forhold til den del af kultur- og folkelivet, der ligger i forlængelse af hans skabelses- og menneskesyn - hvad der derimod svækker denne sammenhæng eller ligefrem opløser den, er i pagt med det onde, er Antikrist som rationalisterne, der syndede mod - bespottede - Helligånden ved at opløse livsfællesskabet mellem Gud og mennesker.

Grundtvig kan dog, ligesom for at vende det onde til (mod) det gode, gå ind i f.eks. rationalismens sammenhæng og 'forvende' dens begreber og opfattelse af tilværelsen i - grundtvigsk forstået åndelig, kristelig retning. Som eksempel på en sådan kontrafakturdigtning kan nævnes "Mindes vi en fuldtro ven", hvor han modog omdigter ikke alene den reformerte engelske salme "If human kindness meets return", men også Rasmus Frankenaus klubvise "Hver glædens ven", samtidig med at han et par år efter videredigter sin nadversalme $\mathrm{i}$ to folkelige sange "Slaverne rådte på $\varnothing$ sters $\emptyset$ " og "Danmark, under vinters hjerte", der viderefører den historisk-poetiske struktur fra "Mindes vi en fuldtro ven" i en folkelig sammenhæng. Det er tydeligt, at det er den reformerte salmes mangel på levende sammenhæng mellem himmel og jord, Gud og mennesker, og den rationalistiske klubvises mangel på sandt fællesskab mellem de mennesker ("venner"), der samles omkring punchebollen, der er årsagen til den konstruktive digteriske konfrontation, som denne kontrafakturdigtning er et udtryk for.

Det er den samme manglende eller smuldrende livssammenhæng, der er den både ydre og indre årsag til Grundtvigs krisedigte fra midten af 1840 'rne. Hans familieliv var begyndt at gå i opløsning, samtidig med at det manio-depressive anfald foråret 1844 understregede hans egen begrænsning og manglende 
kirkelige og folkelige gennemslagskraft. Krisedigtene giver et utilsløret billede af det menneskelige og kristelige selvopgør, der er baggrunden for den personlige og kirkelige vending Grundtvig oplevede i mødet med Marie Toft december 1845 og umiddelbart efter i salmesangen ved juledagsgudstjenesten i Vartov, kun ganske kort tid efter det sviende nederlag det var for ham at opleve Københavns Præstekonvents afvisning af 'Prøveheftet', det pilotprojekt til en ny salmebog, som han havde været den drivende kraft bag. De næste fem år indtil ægteskabet med Marie Toft var en omtumlet regenerationstid, der både menneskeligt og kristeligt afspejler sig i en salme som "Skyerne gråner og løvet falder", og som resulterede $i$, ikke en tilbageerobring af den gamle tabte sammenhæng, men i en ny, eskatologisk sammenhæng, hvor menneskeligt og kristeligt, personligt, kirkeligt og folkeligt gik sammen i en ny enhed. Et vidnesbyrd om denne nye menneskelige og kristelige livssammenhæng er den række af bearbejdelser af ældre salmer, der fik deres endelige form i begyndelsen af 1850'erne, hvoraf de mest kendte er "O, kristelighed", "I al sin glans nu stråler solen" og "Herren han har besøgt sit folk".

\section{Menneskeligt og kvindeligt}

Grundtvigs forståelse af det menneskelige og det kristelige har hans mosaisk-kristelige anskuelse som sin nødvendige forudsætning. Det samme har hans opfattelse af det kvindeliges betydning, og ligesom den mosaisk-kristelige anskuelse var dannet på baggrund af, hvad man kunne kalde en blanding af intensiv bibellæsning og sund fornuft, skyldes hans kvindesyn en kombination af teologiske og antropologiske overvejelser.

Grundtvig bestemte det kvindelige som, hvad man kunne kalde den frugtbare modtagelighed eller den produktive receptivitet. Sådan var de bibelske kvinder fra Eva til Maria beskrevet, og sådan var det europæiske kvindeideal, hvilket igen stemte overens med den traditionelle opfattelse af kvindens biologiske opgave i forplantningen, hvor man opfattede kvinden som den passive part. Da man ikke havde kendskab til de kvindelige ægcellers eksistens før opfindelsen af mikroskopet og von Baers påvisning af den 1826, opfattede man indtil da den mandlige sæd som det eneste 
aktive princip i forplantningen, idet kvindens indsats indskrænkede sig til at give sæden og fosteret gode udviklings- og vækstbetingelser.

Denne traditionelle opfattelse af kvindens væsen svarede $i$ det store og hele til en traditionel luthersk opfattelse af, hvad det vil sige at være menneske $\mathrm{i}$ forhold til Gud, nemlig som den der både i skabelse og genløsning er den modtagende part, hvis opgave det er at tage imod, lade sig præge og i givet fald arbejde videre med det, der bliver givet. For Grundtvig har dette sammenfald af den traditionelle kvindeforståelse og det luthersk-teologiske menneskesyn betydet, at han har forstået mennesket som kvindeligt i forhold til Gud, hvilket igen betyder, at han har opfattet menneskets natur som dybest set kvindelig. Da Grundtvig udfra sit kvindesyn har opfattet kvindens moderrolle som det fornemste udtryk for hendes frugtbart modtagende natur, har han naturligt kunnet knytte til ved forestillingen om kirken som de kristnes moder: "Kirken er som Himmerige,/ Meget kan den lignes ved,/.. Mest dog som en Barnemoder,/ .." o.s.v.

Grundtvig har i en lang række salmer givet udtryk for sin opfattelse af det menneskeliges og det kristeliges kvindelige sammenhæng, og det er tydeligt, at han er sig fuldt bevidst om betydningen og rækkevidden såvel menneskeligt som kristeligt af dette kvindesyn. Hele sin salmedigtning igennem bruger Grundtvig kvindelige billeder og begreber, hvor der er tale om livsfællesskab både $\mathrm{i}$ forhold til Gud og mennesker, da det kvindelige er det menneskelige - og det gud-menneskelige - livsfællesskabs princip. Således er det hele vejen igennem salmen "Herren han har besøgt sit folk" det kvindelige, der forbinder himmel og jord, Gud og mennesker $\mathrm{i}$ den dobbelte kvindelige sammenhæng, der forbinder Kristus med os og os med Kristus, Maria og kirken, idet Maria og kirken i deres kvindeligt-produktive receptivitet er eet som kristent-livgivende princip.

Det er ikke alene de bibelske kvinder, Grundtvig henviser til, når han skal anskueliggøre det kvindeliges betydning for forståelsen af den menneskelige livssammenhæng. I "Smuler under Herrens bord" glider omtalen af den kananæiske kvinde over i en skildring af hans egen mor og med hende alle kristne mødre som bindeled mellem Himmel og jord, og $\mathrm{i}$ mindetalen over Marie Toft året efter hendes død siger han om hende, hans anden hustru, at han 
"har aldrig kiendt nogen Kvinde, der saa godt som hun, kunde klare for sig selv, hvad det Menneskelige har med det Guddommelige og det Folkelige med det Christelige at giøre" hvilket med andre ord vil sige, at han aldrig har oplevet sammenmhængen mellem det menneskelige og det kristelige så eksistentielt nærværende som i samlivet med hende. Et par år i forvejen, nærmere betegnet 2 måneder før han blev forlovet med. Marie Toft skriver Grundtvig, at "alt hvad der ordentligviis skal gaae os til Hjerte, maa gaae giennem Kvinden til os! Kvinden er nemlig Menneske-Hjertet selv i sin yndigste Aabenbarelse og levende Rørelse, er altsaa den igrunden altid sig selv lige, til Verdens Ende udødelige Menneske-Natur, hvori det maae levende indpræge sig og hvorigiennem det levende maae udtrykke sig, hvad Indtryk Historien virkelig giør paa Naturen, Menneske-Historien paa Menneske-Naturen."

Det kvindelige som udtryk for det menneskelige fik så stor betydning for Grundtvig, som det fik, fordi det i sig forenede det menneskelige og det kristelige, det teologiske og det biologiske på en måde, som han ikke kendte andetstedsfra. Denne enhed truede den moderne naturvidenskab med at slå i stykker, eller rettere: ved at forelægge de seneste resultater vedrørende kvindens rolle i forplantningen anfægtede den moderne naturvidenskab ikke alene den traditionelle opfattelse af kvindens natur, den satte også spørgsmålstegn ved det menneskesyn og den mosaisk-kristelige anskuelse, der for Grundtvig hørte uløseligt sammen med den kvindelige produktive receptivitet. Et par uger før den ovenfor citerede betragtning om kvindens væsen skriver Grundtvig om netop dette spørgsmål $\mathrm{i}$ en anmeldelse af Mathilde Fibigers brevroman Clara Raphael. 12 Breve, at "Adam tog ikke feil, da han kaldte sin Kone Eva eller "de Levendes Moder" det lærer hver Dags saavelsom Aartusinders Erfaring, og dog er jo næsten alle vore "studerede" saakaldte oplyste Folk nu saa splittergale, eller saa umenneskelige, at de fradømmer, om ikke Kvinden, saa dog Kvindeligheden, som er den lyslevende Menneskenatur, alt overdyrisk, som de kalder oversandseligt, følgelig alt menneskeligt Indhold."

Grundtvig ved, at han er i håbløst mindretal, i hvert fald i den akademisk dannede verden med sin fastholden ved det gamle verdens- og menneskesyn, men han er fuldt og fast overbevist om, 
at den gamle verdensforståelse er nødvendig for at fastholde både den mosaisk-kristelige anskuelse og den kristne tro. Verdenssyn og menneskeforståelse, skabelsesbevidsthed og kristentro hører uløseligt sammen, falder den ene, falder de alle med den. Grundtvig vidste, hvad der stod på spil, og han vidste, at det var hans gudgivne opgave at holde stand, koste hvad det ville, mod den gudløse, åndsnedbrydende og menneskefjendske rationalisme, der truede med at lægge verden øde. Oplevelserne i december $1845 \mathrm{og} \mathrm{i}$ årene derefter havde vist ham, at det kunne nytte, for Gud havde allerede vendt strømmen, hvad de rationalistiske jætters rasen i virkeligheden også var et umiskendeligt tegn på.

\section{Sangen}

Grundtvig har som alle sine samtidige, eller i hvert fald dem, der lagde mærke til, hvad det var, der skete rundt omkring dem, oplevet sangen som en af de grundlæggende både menneskelige og kristelige livsytringer. Sangen har som arbejdssang, vandresang, selskabssang $i$ videste betydning og som salmesang ikke alene ved gudstjenesten om søndagen, men også til hverdag ved den daglige morgen- og aftenandagt i hjemmene fyldt tilværelsen ud. Det er muligt, at de fleste ikke har sunget særligt smukt, hvad Grundtvig med sin mangel på sangstemme dog næppe har bebrejdet dem, men de sang, og når de kom i kirke og sang salmer, var det derfor naturligt for dem at synge med, også fordi de som med viserne derhjemme kunne salmerne udenad og derfor uden at tænke over det oplevede dem som det naturlige udtryk for deres egen kristendom. Af samme grund mindedes Grundtvig også fra sin barndom den jublende salmesang ved højtiderne, ikke mindst ved juletid. Denne gamle, selvfølgelige salmesang huskede han både fra sit barndomshjem i Udby og fra Tyregod, hvor han blev forberedt til latinskolen i Aarhus af pastor Laurids Feld. Men han huskede også, hvordan rationalismen, repræsenteret af Evangeliskkristelig Psalmebog, havde taget livet ikke alene af salmesangen, men også af den folkelige kristendom i størstedelen af landet bortset fra de nordvestlige dele af Jylland, hvor man holdt fast ved Kingos salmebog. Denne oplevelse er en væsentlig årsag til den kamp på liv og død, han livet igennem førte mod rationalismen, 
og det had han nærede mod dens salmebog. Alene ved hjælp af sin salmebog havde rationalismen i bogstaveligste forstand lukket munden på den folkelige kristendom og kvalt den. Derfor var det lige fra hans lutherske vakkelse 1810-11 og livet ud et af hans vigtigste mål at få den danske menighed til at synge igen. Salmesangen var det levende udtryk for fællesskabet mellem Gud og mennesker og mellem mennesker indbyrdes, det fællesskab, rationalisterne havde slået i stykker, og som det gjaldt om at få genskabt. På denne baggrund kunne han kun opleve gennembruddet i Vartov juledag 1845 som et udtryk for, at rationalismens magt var brudt. Ikke mindst da gennembruddet skete med "Et barn er født i Betlehem", hvor menighedens og englenes julesang går op $\mathrm{i}$ en højere enhed som den evige lovsang, der binder verdens skabelse og fuldendelse sammen med Jesu fødsel i Betlehem.

\section{Struktur og sammenhoeng}

Grundtvigs salmedigtning skal forstås i tæt sammenhæng med hans liv og virksomhed iøvrigt. Ikke alene salmedigtningen som genre, men helt ned i salmernes mindste detaljer. Christian Thodberg har påvist, hvordan Grundtvigs prædikener, indtil hans salmedigtning for alvor begynder i midten af 1830'erne, indeholder lange sekvenser med rytmisk prosa, der lader sig skrive ud som kortere og længere, til tider endog meget lange prosadigte, et forhold som Grundtvig uden tvivl selv har været opmærksom på, sådan som det fremgår af en betragtning fra omkring 1813 om, at "Talen er mere velklingende alt som den nærmer sig Verset, og $\mathrm{i}$ den velklingende Prosa er altid et Versemaal forborgent." Det er i vid udstrækning muligt ikke mindst ved en nærlæsning af Grundtvigs prædikener at følge hans arbejde med de tanker, der får deres endelige form i salmerne. Det er tydeligt, at Grundtvig opfatter den bundne, metriske form i salmerne som et bedre og klarere medium for det, han vil udtrykke, end f.eks. prædikenernes prosa. Rytme og struktur er bevidst anvendt til at udtrykke salmernes stemning, og indhold; som eksempler kan nævnes dels krisedigtene fra 1840'erne, der for manges vedkommende har nogenlunde den samme udvidede anapæstiske rytme, dels den kontrasterende 
parallelisme, som en lang række salmer er bygget op over for at indbygge $\mathrm{i}$ dem den vending $\mathrm{i}$ forhold til rationalismens livsopløsende kræfter, han i mange år forudså og senere kunne konstatere, ligesom der i mange salmer kan påvises en parallelstruktur eller en udviklings- eller vakst-struktur, der beskriver udviklingen fra død til liv og fra mørke til lys. Dertil kommer, at salmerne kan være bygget op over varianter af hovedstrukturerne, ligesom de kan indeholde et kompliceret net af over- og underordnede strukturer. Fælles for strukturerne er, at de skal belyse indholdet. Ved en senere bearbejdning, der betyder en forskydning af indholdet, kan salmen således skifte struktur; et eksempel er "Herren, han har besøgt sit folk", der i 1836 er opbygget over den parallelt-kontrasterende V-struktur, men i 1853-versionen, der afspejler den nye situation efter 1845 , er denne struktur, der forudsætter en profetisk opfattet vending, blevet suppleret med en vækst- eller udfoldelsesstruktur, der angiver en jævn og sikker udvikling frem mod det mål, der ligger forude, og som profetisk allerede er foregrebet $\mathrm{i}$ udviklingen frem mod det.

\section{"Guds menighed, syng for vor skaber $i$ løn", en salmeanalyse}

Et eksempel på, hvordan form og indhold gensidigt betinger og underst $\varnothing$ tter hinanden, er salmen "Guds menighed, syng for vor skaber i løn" fra 1847, der afspejler dels det kirkelige gennembrud 1845 , dels den enhed af det kristelige og menneskelige, som netop dette gennembrud gjorde det muligt for ham at tro på som den danske kirkes, eller som han foretrak at sige: den danske menigheds fremtidige virkelighed.

1 Guds Menighed, syng for vor Skaber i Løn,

- Engle synge med -

Som gav os til Frelser sin enbaarne Søn.

Saa liflig lege vi for vor Herre! 
2 Slaae Harpen, du fromme Psalmist paa Jord,

- Strængen er af Guld -

For Jesus vor Konge, Guds levende Ord.

Saa liflig lege vi for vor Herre!

3 Da høres de glødende Tungers Røst,

- Aanden er os nær -

Som bringer os altid den evige Trøst.

Saa liflig lege vi for vor Herre!

N.F.S. Grundtvig 1847

"Guds menighed, syng for vor skaber i løn" er skrevet i løbet af efteråret $1847 \mathrm{i}$ forlængelse af Grundtvigs arbejde med en folkeviseudgave samme eftersommer. Han har, både hvad form og indhold angår, ladet sig inspirere af visen om Guldharpen, "Hr. Villemand og hans M $\varnothing$ saa pur", der handler om, hvordan åmanden trods alle sikkerhedsforanstaltninger bemægtiger sig hr. Villemands brud, da hun på vej til deres bryllup skal over Blidebro, og hvordan hr. Villemand da ved sit harpespil gør åmanden kraftesløs og tvinger ham til at slippe sit bytte igen. Grundtvig tager fra folkevisen tanken om musikkens og sangens magt til at mane det onde ned og det gode frem, ligesom han henter versemålet med det dobbelte omkvæd fra folkevisen, der som fast mellemomkvæd har "Strengen er af guld" og som slutomkvæd "Så liflig leged han for sin jomfru!".

Baggrunden for "Guds menighed, syng for vor skaber i løn" er en kombination af folkevisens tanke - og folkelige erfaring - om sangens mágt, og Grundtvigs egen forestilling om og oplevelse af det samme. Ikke mindst havde Grundtvig i sin menighed i Vartov oplevet salmesangens betydning. Han havde set, hvordan sangen ikke alene udøvede en sælsom magt over dem, der sang, men også så at sige fremtvang, fremmanede den virkelighed, den beskrev. For dem, der oplevede salmesangen i Vartov kirke, var det, som om himlen åbnedes og englene steg op og ned på salmens tonestige. Folkevisen, her visen om "Hr. Villemand og hans Mø saa pur" lærte Grundtvig, at denne oplevelse ikke alene var hans egen og Vartov-menighedens, og at den ikke kun gjaldt salmesangen; der var tale om en almindelig folkelig-menneskelig erkendelse og 
oplevelse af sangens magt, der stod i det godes og dermed i Guds tjeneste. Bag "Guds menighed, syng for vor skaber i løn" ligger en kristelig-folkelig helhedsforståelse af sangens betydning.

"Guds menighed, syng for vor skaber i løn" har med sine tre strofer en struktur, der på én gang er både klar og kompliceret. De tre strofer indeholder samtidig en opfordring til og en beskrivelse af den kristne menigheds lovsang til den treenige Gud, Faderen ("vor Skaber" i strofe 1), Sønnen ("Jesus" i strofe 2) og Helligånden ("Ånden" i strofe 3). De tre strofer kan fordeles på de kirkelige højtider, Julen, hvor Gud giver os sin Søn, Påsken, hvor Kristus giver os sig selv, og Pinsen, hvor Helligånden giver os det evige livsfællesskab med Faderen og Sønnen. Samtidig repræsenterer de tre strofer de tre verdensaldre, Det gamle Testamentes, der indledes med skabelsen, Det nye Testamentes, da Guds Ord kom til verden, og kirkens, der begyndte, da Helligånden blev sendt til verden, d.v.s. hele universalhistoriens tidsramme.

Der er salmen igennem en stadig bevægelse fra det, der var og er, til det, der skal komme, svarende til verdenshistoriens og gudsfolkets bevægelse fra skabelse til fuldendelse. Salmen går fra en beskrivelse af kristendommens objektive indhold i strofe 1, hvor Det gamle og Det nye Testamentes grundlæggende kendsgerninger nævnes, over formidlingen af dette indhold gennem den profetiske sang og Guds levende Ord i strofe 2, til menighedens og den enkeltes tilegnelse af indholdet i strofe 3. Sagt på en anden måde: Strofe 1 og 2 skildrer henholdsvis den historiske og den poetiske bevægelse frem mod det livsfællesskab med Gud og mennesker, i Helligåndens samfund, som strofe 3 beskriver. Sammenhængen mellem de tre strofer understreges af, at deres enkelte linier svarer parallelt til hinanden.

Sammen med den tredelte opbygning findes der en todelt opbygning i salmen. Den første del, der går til og med linie 2 i strofe 2, handler om det gamle menneske, som Gud gav sin enbårne Søn, og den anden del, der omfatter resten af salmen beskriver situationen for det nye menneske, der lever med Guds Søn.

Strukturen i de enkelte strofer er præget af folkeviseformen fra "Hr. Villemand og hans Mø saa pur" med to rimede linier efterfulgt af henholdsvis et frit mellemomkvæd og et fast slutomkvæd. 
Førstelinierne handler om en menneskelig aktivitet, der sker i en guddommelig sammenhæng. Denne sammenhæng beskrives og forklares nærmere $i$ andenlinierne, der igen leder frem til en skildring i tredielinierne af den treenige Guds aktivitet, hvorefter fjerdelinierne beskriver det kristne, genfødte menneskes naturlige reaktion, lovsangen, der er Guds Ords spontane menneskelige genlydsord. En særlig interesse samler sig omkring tredielinierne, der beskriver, hvordan Kristus er Treenighedens forbindende moment, formidlingen (str. 2) mellem det objektive frelsestilsagn (str. 1) og den subjektive frelsestilegnelse (str. 3).

I forlængelse heraf rummer strofe 2 nøglen til en forståelse af salmen. Rent formelt er det denne strofe, der kommer tættest på folkevisen. Mellemomkvædet er det samme, og der tales i linie 1 om det harpespil, hvis livskraft er folkevisens indhold. Grundtvig kalder harpespilleren "Du fromme Psalmist på jord" og lader derved hr. Villemand og kong David glide umærkeligt over i hinanden, samtidig med, at Jesus i linie 3 kaldes både "vor Konge" og "Guds levende Ord": han er Guds og Davids søn på samme måde som harpespilleren er både hr. Villemand og kong David. I Kristus, og med ham i kristendommen, mødes det guddommelige og det menneskelige, det himmelske og det jordiske, og det kristelige og det folkelige går $\mathrm{i}$ det kirkelige, $\mathrm{i}$ Helligåndens samfund, op i en ny og større enhed. Det menneskelige (1:1) og det kristelige (1:3) mødes gennem det bibelske og folkelige (2:1) i Jesus Kristus (2:3), og er gennem ham forenet (3:1) til det evige livs fællesskab mellem Gud og mennesker i Helligåndens samfund (3:3): Det er, sådan som slutomkvædet gentager det efter hver strofe, i sangen, - salmen -, mennesker kan beskrive og opleve dette livsfællesskab ("liflig, "livlig" = "levende" i aktiv betydning) med Gud ("vor Herre") og mennesker. At der her er tale om en grundlæggende struktur ikke alene i kristen-, men også i menneskelivet, finder Grundtvig bekræftet i ligheden mellem hr. Villemand og David. Begges harpe havde "strenge af guld" og begge kunne de ved deres spil få bugt med det onde og vende sorg til glæde; ja, de var i stand til med deres spil at trodse døden og viste derved hver i deres sammenhæng hen til "Jesus, ... Guds levende Ord" og hans sejr over døden i opstandelsen Påskemorgen. 
"Guds menighed! syng for vor skaber i løn" viser Grundtvigs vurdering af det menneskeligt-folkelige i dets forhold til det kristelige, og omvendt. Det menneskelige og folkelige befinder sig i denne verden og er begrænset af den, er uigenkaldeligt "på jord" og "i løn", men er ikke desto mindre Guds skabning, der kan lovsynge ham med levende ord og glødende tunger. Lovsangen er som en skabningens indre struktur, der hvor den møder "Guds levende Ord", selv bliver en del af den evige lovsang (1:2). Folkevisen var for Grundtvig et udtryk for, hvordan den folkelige sang både er årsag til og tegn på folkeligt liv; derfor var der for ham et indre fællesskab mellem folkevisen og salmen, der, det vidste han af egen erfaring, var både årsag til og udtryk for det kirkelige liv, han så omkring sig.

"Guds menighed! syng for vor skaber i løn" blev første gang sunget som julesalme i Julen 1847 og har ved den lejlighed utvivlsomt været med til at lade menigheden i Vartov opleve, at "engle synge med". Et halvt år senere tog Grundtvig den med i sit salmehefte til Kristi Himmelfart og Pinse i Vartov, og den har da sikkert i ligeså høj grad givet menigheden indtryk af, at "Ånden er os nær".

Grundtvigs salmedigtning forener i en sådan grad teologisk og digterisk kvalitet, at de enkelte salmer ikke alene er præcise udtryk for hans tanker og forestillinger, men også fremtræder som åndshistoriske og dermed både kirkehistoriske og kulturhistoriske kraftfelter. 